\title{
A Comparative Analysis State Owned and National Private Bank's Financial Performance
}

\author{
Desi Susilawati ${ }^{1, *}$, Siwi Setya Dewi ${ }^{2}$ \\ ${ }^{1,2}$ Acoounting Vocational Program, Universitas Muhammadiyah Yogyakarta, Indonesia \\ *Corresponding author.Email:desisusilawati@umy.ac.id
}

\begin{abstract}
Bank is one of the institutions that play an important role in the economy of a country, bank has a function as intermediation function is to collect funds and distribute it. The global financial crisis hit over the world . Banks have liquidity difficulties, asset quality down, unable to create earnings and eventually capital is drained in time very fast. Since then the moneter regulation has change to improve development to increase growth and trust from society. The competition between state owned banks as well as with other national private banks which is unavoidable.. Public need the information about the performance of a bank as consideration the public in making decisions. Financial ratio analysis to measure financial performance is needed so the external investor or potensial investor, all interest parties can enrich their understanding about financial performance. The purpose of this research is to determine the results of the comparison of financial performance between state owned bank (Bank mandiei )and national private bank (BCA) in the 2016-2019 periods using the ratio of CAR, NPL, ROA, BOPO, LDR, and NIM. The data analysis method used in this research is hypothesis testing using the independent sample t-test. The results showed that the financial performance at the ratio of CAR, ROA, and NIM, there is a significant difference between State owned banks and National Private Banks. Meanwhile, there is no significant difference in the financial performance of the NPL, LDR, and BOPO ratios. State owned banks have the excellent of financial performance in the ratio of NPL, NIM, and BOPO. Meanwhile, National Private Banks in the CAR, ROA and LDR ratios.
\end{abstract}

Keywords: Financial Performance, Financial Ratios, State owned banks, National Private Bank

\section{INTRODUCTION}

Law (UU) No. 10 year 1998 regarding Banking describes that a bank is a business entity collecting people's funds in the form of savings and distributes them to people in the form of credits and/or other forms in order to improve people's standard of living. Since Bank Global Crisis in 1998. Banks have liquidity difficulties, insufficient capital and unable to create earning. Since then the moneter regulation has change to improve and increase Bank growth and restore trust from society. Therefore Public need the information which describe the bank's performamce as a consideration to make decision.

State own Bank and National private Bank have a competition to restore public trust. State own Bank and National private Bank should manage internal and external factors which influence financial or non financial performance.

Financial performance is a work achievement in financial field attained by a company and attached in the company's financial report. It can assess a company financial performance by using analysis tools.
The effective and ineffective terms of bank financial performance are more popular nowadays. Actual events regarding banking such as merger and liquidation are always linked to bank financial performance. Hence, a bank needs an analysis to determine its conditions after performing operational activities in the certain periods.

The analysis conducted in this context is financial performance assessments of State own and national private bank. Most of general public are recently interested in investments by both investing their capitals and saving their funds. Nonetheless, some of them are able to understand the company's financial performance condition. Therefore, this research would like to conduct helping the public by providing the information respecting financial performances of the banking companies namely Bank Mandiri as state owned bank and Bank Central Asia (BCA) as private national bank.

The reason why this study case choose Bank Mandiri and BCA as the research object because Referring to data from the Financial Services Authority (2019), these two banks showed almost similarity of profit growth. Bank Mandiri's profit growth was Rp. 25.01 trillion to Rp. 27.48 trillion at the end of 2019. Meanwhile, Bank Central Asia 
(BCA) posted a net profit growth of Rp. 25.9 trillion to 28,6 trilliyun. And these two bank have similarity ammount of Aset.

This study would like to discuss how the results of financial performances comparison between the state owned bank and the national private bank. It will determine which bank that has the better performance in order to convey information toward the investors for investing their capitals or saving their funds by applying several ratios, There many Indicators to measure bank's performance. This research using bank financial performance consist of The profitability aspect ROA, while the risk aspect can be proxied by credit risk (NPL ) liquidity risk (LDR) interest risk or market risk (NIM) and operational risk (BOPO).

Capital Adequacy Ratio (CAR), Non-performing Loan (NPL), Return on Assets (ROA), operational expenses/operational income or it can be abbreviated in Indonesian as BOPO, Loan to Deposit Ratio (LDR), and Net Interest Margin (NIM) on Bank Mandiri and BCA in the period 2016-2019.

This research aims to understand the financial performances of the state owned bank and the national private bank and which of them has the better financial performance in order to provide information toward the investors for investing their capitals of saving their funds. The novelty of this study is to add a variable of Net Interest Margin Nonperforming Loan (NIM).

\section{LITERATURE REVIEW}

Based on stakeholder theory, a company should increase its reputation among its principal stakeholders, which has implications for improving financial performance (Kosasih , 2021) Banks can publish financial information or other indicator for measure management performance. Many previous research used financial ratio such as ROA, CAR, NPL which affected to financial performance but it found various result. This result re examine those ratio but we use comparative analysis between State owned Bank and Private Banks

\subsection{Bank Financial Performance Based on CAR}

Capital Adequacy Ratio (CAR) is a capital ratio that shows the bank's ability to provide funds for business development purposes and accommodate the risk of loss of funds caused by bank operations. CAR is indeed very important for a bank because it shows the bank's ability to maintain sufficient capital

Quyen et.al (2021) state-owned banks operate more efficiently than other banks because they are easily linked to the government's sponsored programs, such as public services and preferential supports. Therefore, these banks will have more opportunities to generate more non-interest income from service fees than other private banks.
Supit, et al (2019), Mointi (2019), Lestari (2014), and Ahmad, et al (2014) stated that according to financial ratio of CAR between state owned bank (State-owned enterprises of Indonesia (BUMN)) and the national private bank, it showed there was no difference. On the one hand, it indicated a difference result at the study conducted by Siallagan and Yuyetta (2016) that financial performance of the state owned bank (BUMN) and the national private bank considered by CAR had a significant difference. For examining whether CAR between BUMN and national private bank is different significantly in the period 2016 - 2019, this research proposes the first hypothesis:

$\mathrm{H} 1$ : There is a significant difference between CAR of Bank Mandiri and BCA.

\subsection{Bank Financial Performance Based on NPL}

Banks are required to always keep credit or nonperforming loans low because it can be effected to bank's health. If Non-Performing Loans (NPL) score is high then it will enlarge bank fees, both asset reserve fees and other costs, so that potential to cause bank losses (Sari, et.al 2012).

Mointi (2019) and Maharani and Affandy (2014) state that it showed no difference based on the financial ratio of NPL between the state owned bank (BUMN) and the national private bank. On the other hand, the researches conducted by Siallagan and Yuyetta (2016), Lestari (2014), and Ferita (2018) indicated the different result namely the financial performance had by BUMN and national private bank considered by NPL had a significant difference. For examining whether NPL ratio between the state owned bank (BUMN) and the national private bank is different significantly in the period 2016 - 2019, this research proposes second hypothesis:

$\mathrm{H} 2$ : There is a significant difference between NPL of Bank Mandiri and BCA.

\subsection{Bank Financial Performance Based on ROA}

Supit, et al (2019) and Silalahi (2018) state that it showed no difference according to ROA of the state owned bank (BUMN) and the national private bank. Conversely, the researches performed by Theis (2016), Ahmad, et al (2014), and Ferita (2018) indicate the different result namely the financial performance had by the state owned bank (BUMN) and the national private bank considered by ROA had a significant difference. For examining whether ROA ratio between the state owned bank (BUMN) and the national private bank is different significantly in the period of 2016 2019, this research proposes the following formulated hypothesis:

H3: There is a significant difference between ROA of Bank Mandiri and BCA. 


\subsection{Bank Financial Performance Based on BOPO}

Lestari (2014), Rositasari (2016), Maharani and Affandy (2014), and Silalahi (2018) state that there was no difference based on BOPO financial ratio between the state owned bank (BUMN) and the national private bank. On the contrary, it showed the different result in research conducted by Mointi (2019) that there was a significant difference on financial performance had by BUMN and the national private bank considered by BOPO. For examining whether BOPO ratio between the state owned bank (BUMN) and the national private bank is different significantly in the period 2016 2019, this research proposes the fourth hypothesis:

H4: There is a significant difference between BOPO of Bank Mandiri and BCA.

\subsection{Bank Financial Performance Based on LDR}

Liquidity Debt ratio has impact to liquidity risk because higher Liquidity Debt ratio will also lead to liquidity risk required to meet up with other customer's demand and thus less profitability or even bankruptcy This shows that LDR and returns are interrelated that, higher liquidity shortage lead to fewer returns (Mustafa,2020)

Ferita (2018) and Rositasari (2016) state there was no difference based on LDR financial ratio between the state owned bank (BUMN) and the national private bank. The researches done by Theis (2016), Ahmad, et al (2014), Siallagan and Yuyetta (2016) oppositely indicated the different result that there was a significant difference on financial performance had by the state owned bank (BUMN) and the national private bank considered by LDR. For examining whether LDR ratio between the state owned bank (BUMN) and the national private bank is different significantly in the period 2016 - 2019, this research proposes the following formulated hypothesis:

H5: There is a significant difference between LDR of Bank Mandiri and BCA.

\subsection{Bank Financial Performance Based on NIM}

Sensitivity assessment of market risk intended to assess the ability bank finance in anticipation of changes in market risk caused byexchange rate movements (Kurniawati, 2012). This research using NIM ratio as proxy of market risk.

There was no difference based on NIM financial ratio between the state owned bank (BUMN) and the national private bank according to Rositasari (2016), Fredy, et al (2017), and Supit, et al (2019). On the one hand, the researches conducted by Ferita (2018), Maharani dan Affandy (2014) showed the different result that there was a significant difference on financial performance had by the state owned bank (BUMN) and the national private bank considered by NIM. For examining whether NIM ratio between the state owned bank (BUMN) and the national private bank is different significantly in the period 2016 2019 , this research proposes the following hypothesis:

H6: There is a significant difference between NIM of Bank Mandiri and BCA.

\section{METHOD}

\subsection{Type and Source of data}

This is a comparative research with a quantitative approach, namely comparative analysis that reports according to facts based on bank financial statements This research used secondary data consisting of annual report data of State owned banks (BUMN) and National Private Banks (NonBUMN) which are listed on the Indonesia Stock Exchange (IDX) which have been published from 2016 to 2019 and accessed through the Indonesia Stock Exchange website (www.idx.co.id).

The framework can be seen as follows:

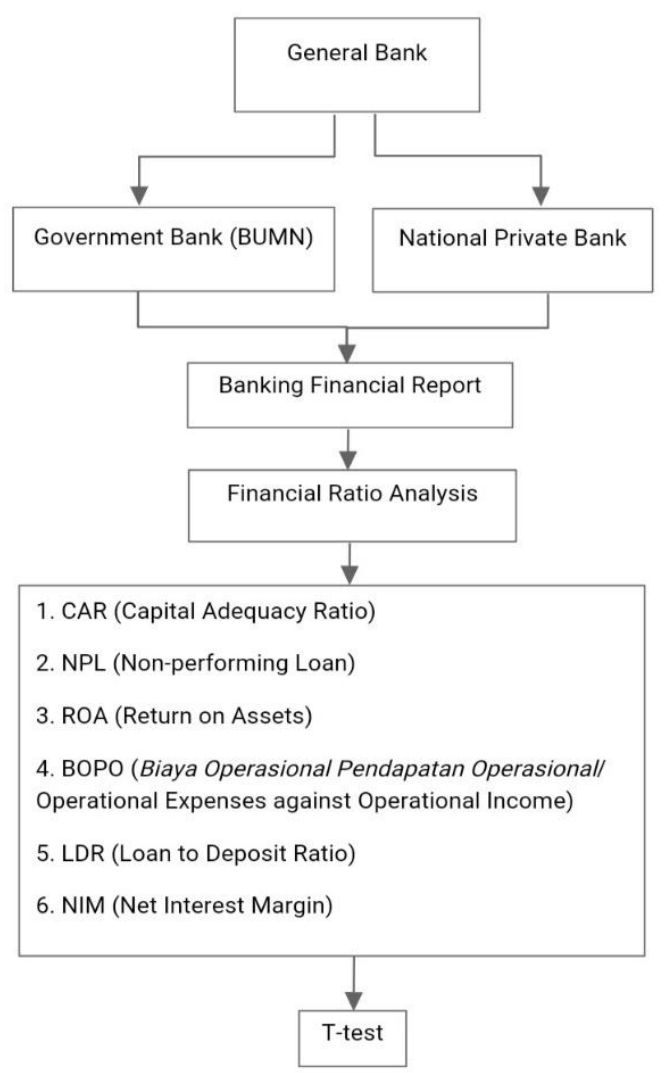

\subsection{Measurement of financial ratio}

\subsubsection{Capital Adequacy Ratio (CAR)}

CAR is a capital adequacy ratio indicating the banking capacity to provide funds used to overcome the loss risk possibility. The greater CAR score reflects the better bank capability to deal with the loss risk possibility. 


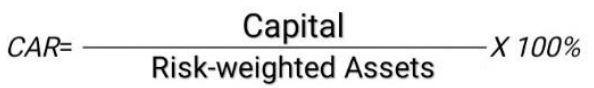

\subsubsection{Non-performing Loan (NPL)}

NPL is a ratio used to measure the amount of nonperforming credit risk in a bank caused by the customer's inability to make payments. The lower NPL score, the lower level of non-performing credit. Thus, the bank's condition will be also better. Subramanyam (2014) states that it can formulate NPL as follows:

$$
\mathrm{NPL}=\frac{\text { Non-performing Credit }}{\text { Credit Total }} \times 100 \%
$$

\subsubsection{Return on Assets (ROA)}

ROA is a ratio for measuring the banking capability to generate profits which is called profitability. The greater ROA score means the better bank capability to earn profits. Frianto (2012) in his book entitled "Manajemen Dana dan Kesehatan Bank" states that it can formulate ROA ratio as follows:

$$
R O A=\frac{\text { Net Profit before Tax }}{\text { Assest Total }} \times 100 \%
$$

\subsubsection{Operational Expenses against Operational Income (BOPO)}

BOPO is a company's profitability ratio illustrating the banking efficiency in performing its activities. The lesser BOPO score, the more efficient bank in operating. BOPO ratio as follows:

$$
B O P O=\frac{\text { Operational Expenses }}{\text { Operational Income }} \times 100 \%
$$

\subsubsection{Loan to Deposit Ratio (LDR)}

LDR is a to measure the credit amount composition given by comparing to the amount of people's funds and self-capital used. The greater LDR score means they bank does not has adequate liquidity for covering the duties toward the customers. Kasmir (2014) in his book entitled "Bank dan Lembaga Keuangan Lainnya" states that it can formulate LDR ratio as follows:

$$
L D R=\frac{\text { Credit Total of the Third Party }}{\text { Fund Total of the Third Party }} \times 100 \%
$$

\subsubsection{Net Interest Margin (NIM)}

NIM is a ratio for measuring a bank management capability in managing its productive assets to generate net interest income. The greater NIM score shows the higher interest income generated. Subramayam (2014) state that it can formulate NIM ratio::

$$
\mathrm{NIM}=\frac{\text { Net Interest Income }}{\text { Productive Asset Average }} \times 100 \%
$$

\subsection{Descriptive Statistical Analysis}

Descriptive statistics is a statistical analysis process focusing on data management, presentation, and classification. By this process, the data presented will be more interesting and understood, as well as able to convey the deeper meaning for the data users.

\subsection{Independent Samples T-test}

This independent samples t-test (t-test of two independent samples), according to Santoso (2014), is to determine the difference or to compare the average of two unrelated groups. Before performing the independent t-test samples testing, it conducted the requirement tests (data normality test and variance homogeneity test) by applying Statistical Package for the Social Science (SPSS) software.

\section{RESULT AND DISCUSSION}

This research reviewed the financial performance comparison between Bank Mandiri and BCA by using CAR, NPL, ROA, BOPO, LDR, and NIM ratios. The results of the calculation and analysis of financial statements at Bank Mandiri and Bank Central Asia (BCA) according to the ratio used as a measuring tool are presented in Table 1

Table 1. The Financial Ratio Analysis

\begin{tabular}{cccccccc}
\hline \multirow{2}{*}{ BANK NAME } & \multicolumn{7}{c}{ Financial Ratio (\%) } \\
\cline { 2 - 8 } & YEAR & CAR & NPL & ROA & BOPO & LDR & NIM \\
\hline \multirow{2}{*}{ STATE OWN } & 2016 & 21,361 & 1,606 & 1,788 & 74,767 & 78,216 & 8,386 \\
BANK & 2017 & 21,642 & 1,247 & 2,415 & 64,748 & 79,834 & 7,687 \\
(MANDIRI) & 2018 & 20,965 & 0,756 & 2,823 & 60,112 & 83,397 & 8,830 \\
& 2019 & 21,387 & 0,859 & 2,764 & 58,454 & 84,042 & 7,054 \\
\hline NATIONAL & 2016 & 22,213 & 1,311 & 3,818 & 51,953 & 77,042 & 6,635 \\
PRIVATE & 2017 & 23,597 & 1,624 & 3,886 & 48,828 & 78,208 & 6,222 \\
BANK & 2018 & 23,951 & 1,291 & 3,965 & 43,868 & 81,253 & 6,167 \\
(BCA) & 2019 & 24,641 & 1,342 & 3,949 & 42,923 & 80,107 & 6,166 \\
\hline Source: secondary data & & & & & &
\end{tabular}




\subsection{Descriptive Statistical Test}

The descriptive statistics in this research presented the amounts of data, minimum scores, maximum scores, means, and standard deviations of the variables of CAR, NPL, ROA, BOPO, LDR, and NIM. The descriptive statistical test result is showed in Table 2.

Table 2. The Descriptive Statistical Test

\begin{tabular}{llrrrrr}
\hline \multirow{2}{*}{ Ratio } & \multicolumn{1}{c}{ Bank Name } & N & Minimum & Maximum & Mean & $\begin{array}{c}\text { Std. } \\
\text { Deviation }\end{array}$ \\
\hline \multirow{2}{*}{ CAR } & Bank Mandiri & 4 & 20.965 & 21.642 & 21.33875 & .279567 \\
& Bank Central Asia & 4 & 22.213 & 24.641 & 23.60050 & 1.021544 \\
\hline \multirow{2}{*}{ NPL } & Bank Mandiri & 4 & .756 & 1.606 & 1.11700 & .388547 \\
& Bank Central Asia & 4 & 1.291 & 1.624 & 1.39200 & .156083 \\
\hline \multirow{2}{*}{ ROA } & Bank Mandiri & 4 & 1.788 & 2.823 & 2.44750 & .475103 \\
& Bank Central Asia & 4 & 3.818 & 3.965 & 3.90450 & .066995 \\
\hline \multirow{2}{*}{ BOPO } & Bank Mandiri & 4 & 42.389 & 45.677 & 44.42200 & 1.502457 \\
& Bank Central Asia & 4 & 42.923 & 51.953 & 46.89300 & 4.252817 \\
\hline \multirow{2}{*}{ LDR } & Bank Mandiri & 4 & 78.216 & 84.042 & 81.37225 & 2.802101 \\
& Bank Central Asia & 4 & 77.042 & 81.253 & 79.15250 & 1.885865 \\
\hline \multirow{2}{*}{ NIM } & Bank Mandiri & 4 & 7.054 & 8.830 & 7.98925 & .781093 \\
& Bank Central Asia & 4 & 6.166 & 6.635 & 6.29750 & .226516 \\
\hline
\end{tabular}

Source: Processed Data, 2020

In accordance with the descriptive statistical test result, it indicated that the average of CAR of BCA was better than Bank Mandiri's. Nonetheless, BOPO of Bank Mandiri was better than BCA's. For the averages of other financial ratios such as ROA and LDR, BCA's was still better than Bank Mandiri's. On the other hand, for the averages of NPL and NIM ratios, Bank Mandiri's was better than BCA's.

\subsection{Data Normality Test}

The normality test result applying One-Sample Kolmogorov Smirnov (KS) test method is presented in Table 3.

Table 3. The Normality Test

\begin{tabular}{cccc}
\hline Ratio & $\begin{array}{c}\text { Kolmogorov-Smirnov } \\
\text { Score }\end{array}$ & $\begin{array}{c}\text { Asymp. } \\
\text { Sig. (2-tailed) }\end{array}$ & Conclusion \\
\hline CAR & 0.224 & 0.200 & Normal \\
NPL & 0.240 & 0.194 & Normal \\
ROA & 0.278 & 0.070 & Normal \\
BOPO & 0.284 & 0.161 & Normal \\
LDR & 0.168 & 0.200 & Normal \\
NIM & 0.186 & 0.200 & Normal \\
\hline
\end{tabular}

Source: Processed Data, 2020

Based on the normality test result above, it indicated that the data had been distributed normally. It was showed by the ratio scores of Asymp. Sig (2-tailed) of CAR that was 0.200 , NPL that was 0.194 , ROA that was 0.070 , BOPO that was 0.161 , LDR that was 0.200 , and NIM that was 0.200 . Each ratio of Asymp. Sig (2tailed) scores was bigger than 0.05 , thus, it can conclude that the data of this study was distributed normally.

\subsection{T-test (Independent Samples t-Test)}

The hypothesis testing in this study used Independent Samples T-test by applying SPSS software. The use of comparative test or SPSS T-test that is a part of parametric inferential statistic which has an advantage in data measurement accuracy is to determine any significant difference between two groups of the different subjects. Table 4 illustrates the result obtained.

Table 4. Independent Samples T-test

\begin{tabular}{|c|c|c|c|c|c|c|}
\hline \multicolumn{7}{|c|}{ Independent Samples Test } \\
\hline & & \multicolumn{2}{|c|}{$\begin{array}{c}\text { Levene's Test for } \\
\text { Equality of Variances }\end{array}$} & \multicolumn{3}{|c|}{ t-test for Equality of Means } \\
\hline & & $\mathrm{F}$ & Sig. & $\mathrm{t}$ & df & $\begin{array}{c}\text { Sig. } \\
\text { (2-tailed) }\end{array}$ \\
\hline \multirow{2}{*}{ CAR } & $\begin{array}{l}\text { Equal variances } \\
\text { assumed }\end{array}$ & 2.405 & .172 & -4.271 & 6 & .005 \\
\hline & $\begin{array}{l}\text { Equal variances } \\
\text { not assumed }\end{array}$ & & & -4.271 & 3.447 & .018 \\
\hline \multirow{2}{*}{ NPL } & $\begin{array}{l}\text { Equal variances } \\
\text { assumed }\end{array}$ & 5.048 & .066 & -1.314 & 6 & .237 \\
\hline & $\begin{array}{l}\text { Equal variances } \\
\text { not assumed }\end{array}$ & & & -1.314 & 3.944 & .260 \\
\hline \multirow[b]{2}{*}{ ROA } & $\begin{array}{l}\text { Equal variances } \\
\text { assumed }\end{array}$ & 5.149 & .064 & -6.073 & 6 & .001 \\
\hline & $\begin{array}{l}\text { Equal variances } \\
\text { not assumed }\end{array}$ & & & -6.073 & 3.119 & .008 \\
\hline \multirow{2}{*}{ BOPO } & $\begin{array}{l}\text { Equal variances } \\
\text { assumed }\end{array}$ & 9.619 & .021 & -1.096 & 6 & .315 \\
\hline & $\begin{array}{l}\text { Equal variances } \\
\text { not assumed }\end{array}$ & & & -1.096 & 3.737 & .339 \\
\hline \multirow{2}{*}{ LDR } & $\begin{array}{l}\text { Equal variances } \\
\text { assumed }\end{array}$ & 2.826 & .144 & 1.314 & 6 & .237 \\
\hline & $\begin{array}{l}\text { Equal variances } \\
\text { not assumed }\end{array}$ & & & 1.314 & 5.255 & .243 \\
\hline \multirow{2}{*}{ NIM } & $\begin{array}{l}\text { Equal variances } \\
\text { assumed }\end{array}$ & 7.170 & .037 & 4.160 & 6 & .006 \\
\hline & $\begin{array}{l}\text { Equal variances } \\
\text { not assumed }\end{array}$ & & & 4.160 & 3.501 & .019 \\
\hline
\end{tabular}

Table 4 shows that Levene's test (F) for CAR scored 2.405 with the probability by 0.172 . Due to the probability score that was greater than $0.05(0.172>0.05)$, it can be said that there was no variance difference (homogenous data) in the two samples used in this study.

If the data was homogenous, so the essential point should be paid attention was the data equal variances assumed. Meanwhile, sig. (2-tailed) score of CAR was 0.005. Because sig. (2-tailed) score was lesser than 0.05 that was $0.005<$ $0.05, \mathrm{H} 1$ was accepted. Hence, it can be said that there was a financial performance difference between Bank Mandiri and BCA considered from CAR.

This occurred because of the existences of capital supplier sources difference and the amount of bank size. The greater bank size, the greater bank investment capability in preventing the possibility of business loss risk existence. However, the high capital owned was able to expand its business more safely. 
This hypothesis testing result was supported by a study conducted by Siallagan dan Yuyetta (2016) analyzing banking financial performance comparison among BPD, state owned banks, national private banks, and foreign bank. This indicated that there was a financial performance difference of state owned banks and national private banks considered from CAR.

In Table 4, it indicates that Levene's test (F) for NPL ratio scored 5.048 with the probability by 0.066 . Due to the probability score that was greater than $0.05(0.066>0.05)$, it can be said that there was no variance difference (homogenous data) in the two samples used in this research.

If the data was homogenous, so the essential point should be paid attention was the data equal variances assumed. Meanwhile, sig. (2-tailed) score of NPL was 0.237. Because of sig. (2-tailed) score that was greater than 0.05 (0.237 > $0.05), \mathrm{H} 1$ was denied. Therefore, it can be said that there was no financial performance difference between Bank Mandiri and BCA considered from NPL.

This happened because those banks had adequate capability in managing credit so that can minimize the existence of non-performing credit. This hypothesis testing was supported by the research conducted by Fredy, et al (2017) that had analyzed the financial performance difference of BUMN bank and national private bank. It showed there was no financial performance difference of them considered from NPL ratio.

This result hypothesis testing was inversely proportional to the research result performed by Siallagan and Yuyetta (2016) stating that there was a different banking financial performance among BPD, BUMN Bank, National Private Bank, and Foreign Bank.

Table 4 describes that Levene's test $(F)$ of ROA ratio scored 5.149 with the probability by 0.064 . Due to the probability that was greater than $0.05(0.064>0.05)$, it can be said there was no variance difference (homogenous data) in the two samples used in this study.

If the data was homogenous, so the essential point should be paid attention was the data equal variances assumed. Sig. (2-tailed) score of ROA ratio was 0.001. Because of sig. (2tailed) score was lesser than $0.05(0.001<0.05)$, H1 was accepted. Therefore, it can be said that there was a financial performance difference between Bank Mandiri and BCA considered from ROA ratio.

This occurred because there were a financial performance difference in generating profits and the amount of assets owned by Bank Mandiri and BCA. It encouraged the investors to invest shares in the banks that were able to generate the most profits.

This hypothesis testing was supported by the research conducted by Theis (2016) that had analyzed the financial performance difference of the government general bank and the national private bank (foreign exchange). It indicated there was a financial performance difference of the state owned bank and the national bank considered from ROA ratio.

This result hypothesis testing was inversely proportional to the research result conducted by Supit, et al (2019) stating that there was no financial performance difference between BUMN bank and National Private General Bank.

Tabel 4 shows that Levene's test (F) of BOPO ratio scored 9.619 with the probability by 0.021 . Because the probability was lesser than $0.05(0.021<0.05)$, it can be said there was a variance difference (inhomogeneous data) in the two samples used in this study.

If the data was inhomogeneous, so the essential point should be paid attention was the data equal variances not assumed. Sig. (2-tailed) score of BOPO ratio was 0.339. Due to the probability that was greater than $0.05(0.339>0.05)$, $\mathrm{H} 1$ was denied. Hence, it can be said there was no financial performance difference between Bank Mandiri and BCA considered from BOPO ratio.

This happened because both of them had adequate capability in managing operational expenses against operational income so that can generate the expected profits.

This hypothesis was supported by the research conducted by Silalahi (2018) that had analyzed the financial performance difference of BUMN bank and the national private bank. It showed there was no financial performance difference of them considered from BOPO ratio.

This result hypothesis testing was inversely proportional to the research result performed by Mointi (2019) stating that there was a different banking financial performance between the state owned bank and the private bank.

Tabel 4 shows that Levene's test (F) of LDR ratio scored 2.826 with the probability by 0.144 . Due to the probability that was greater than $0.05(0.144>0.05)$, it can be said there was no variance difference (homogenous data) in the two samples used in this study.

If the data was homogenous, so the essential point should be paid attention was the data equal variances assumed. Sig. (2-tailed) score of LDR ratio was 0.237. Because of the probability that was greater than $0.05(0.237>0.05), \mathrm{H} 1$ was denied. Therefore, it can be said there was no financial performance difference between Bank Mandiri and BCA considered from LDR ratio.

This occurred because both of them had adequate capability in carrying out management strategy, collecting funds, and distributing loan.

This hypothesis was supported by the research conducted by Silalahi (2018) that had analyzed the financial performance difference of BUMN bank and the national private bank. It indicated there was no financial performance difference of them considered from LDR ratio.

This result hypothesis testing was inversely proportional to the research result performed by Theis (2016) stating that 
there was a different financial performance between the state owned bank and the private bank.

Table 4 indicates that Levene's test (F) of NIM ratio scored 7.170 with the probability by 0.037 . Due to the probability that was lesser than $0.05(0.037<0.05)$, it can be said there was a variance difference (inhomogeneous data) in the two samples used in this study.

If the data was inhomogeneous, so the essential point should be paid attention was the data equal variances not assumed. Sig. (2-tailed) score of NIM ratio was 0.019. Due to $1 \mathrm{Sig}$. (2-tailed) score that was lesser than $0.05(0.019<0.05)$, $\mathrm{H} 1$ was accepted. Hence, it can be said there was a financial performance difference between Bank Mandiri and BCA considered from NIM ratio.

This happened because there was the capability difference in managing their productive assets for generating interest income from the bank operational activities performed by both banks. It encouraged the investors to invest funds in the banks that are able to manage their productive assets for earning interest income.

This hypothesis was supported by the research conducted by Ferita (2018) regarding the financial performance comparison between BUMN bank and Private-owned General Bank. It indicated there was a financial performance difference between them considered by NIM.

This result hypothesis testing was inversely proportional to the research result performed by Supit, et al (2019) stating that there was no financial performance difference between BUMN bank and National Private General Bank.

\section{CONCLUSIONS AND RECOMMENDATION}

\subsection{CONCLUSIONS}

According to the financial performance analysis of the State owned bank (BUMN), in this case, namely PT Bank Mandiri (Persero) Tbk and the National Private Bank, in this case, namely PT Bank Central Asia Tbk (BCA) which are listed on the Indonesia Stock Exchange for the period 2016 2019 which are represented by financial ratios consisting of CAR, NPL, ROA, BOPO, LDR, and NIM, it concludes that:

(1) Based on the results research on CAR, ROA, and NIM ratios, it obtained that there was a financial performance difference between the state owned bank and the national private bank.

(2) Based on the results research on NPL, BOPO, and LDR ratios, it obtained that there was no financial performance difference between the state owned bank and the national private bank.

\subsection{RECOMMENDATION}

Several suggestions can be proposed from the study results are as follows:
(1) BCA should be able to supervise or select the creditors more carefully in giving loan to the customers needing expenses in order to minimize the existence of non-performing credit.

(2) Bank Mandiri should improve its financial performance on ROA ratio in order to be able to generate more profits and to compete with the national private bank.

(3) The future researchers are expected to be able to conduct researches with other variables beyond this variable, for instances, by evaluating factors influencing the bank health condition in Indonesia deeper and gaining more varied results.

\section{REFERENCE}

[1] Ahmad, Gatot Nazir., et al. 2014. "Comparative Performance Analysis of State-Owned Foreign Exchange Banks and Private Foreign Exchange Banks in 2006-2011". Indonesian Science Management Research Journal (JRMSI). Vol 5 (1)

[2] Badan Pusat tatistik, 2020. Banks and Bank Offices 2014-2019. [On line]. Jakarta (ID): Central Bureau of Statistics. [July 15, 2020]. Available: http://www.bps.co.id.

[3] Bank Performance. 2019. Rating of Commercial Banks Based on Total Assets. [Online]Available: https://www.kinerjabank.com/peringkat_bank. [July 15, 2020]

[4] Bank Indonesia Circular Letter No. 13/24/DPNP Dated October 25, 2011 concerning Assessment of Commercial Bank Soundness Level.

[5] Bank Indonesia Regulation Number 13/1/PBI/2011 concerning Assessment of the Soundness of Commercial Banks.

[6] Fredy, Hotman., et al. 2017. "Comparative Analysis of the Financial Performance of BUMN Commercial Banks and Private Commercial Banks Listed on the Indonesia Stock Exchange in 2011 - 2015”. Journal of Business Research. Vol 1 (1)

[7] Indonesian Accounting Association. PSAK No. 1 Regarding Financial Statements - revised edition 2015. Publisher of the Financial Accounting Standards Board: PT. King of Grafindo

[8] Indonesian Institute of Accountants. 2013. Financial Accounting Standards. Jakarta : Salemba Empat

[9] Government of the Republic of Indonesia. 1998. Law Number 10 of 1998 concerning Banking. Jakarta (ID): Bank Indonesia.

[10] Juliana, Fansisca Ferita. 2018. "Comparative Analysis of the Financial Performance of State-Owned Banks and PrivateOwned Commercial Banks Listed on the Indonesia Stock Exchange for the Period 2012-2016". Management Study Program at Mercu Buana University Jakarta: Unpublished Thesis

[11] Kasmir. 2014. Banks and Other Financial Institutions. Jakarta : PT. King Grafindo Persada

[12] Kosasih, W.D., Rahman, A.F., \& Prastiwi, A. (2021). Does Sustainable Banking Disclosure Affect Bank Efficiency? Evidence from Indonesia. Journal of Accounting and Investment, vol 22 , No (2), 
[13] Kurniasari. 2014. Analysis of Concept and Application Financial Statements. Edition 3. Jakarta: Erlangga

[14] Kurniasari. S,. 2012 Comparative Analysis Of Banking Financial Performance

[15] Sharia Used The Camels Method Before, During And After The Global Crisis Of 2008, Journal of Accounting\& Investement Vol 13 No.2

[16] Lestari, Diane. 2014. "Comparison of Financial Indicators Between State-Owned Commercial Banks and National Private Commercial Banks in Indonesia. Journal of Development Economics. Vol 12 (2)

[17] Maharani, V. P \& Affandy, C. 2014. "Comparative Analysis of the Financial Performance of State Banks and Private Banks on the Indonesia Stock Exchange (IDX) for the Period 2008 2012". Management Insights. Vol 9 (1)

[18] Munawir, S. 2012. Analysis of Financial Information. Yogyakarta: Liberty

[19] Omer Allagabo Omer Mustafa Impact of Liquidity Shortage Risk on Financial Performance of Sudanese Islamic Bank International Journal of Islamic Economics and Finance (IJIEF) Vol. 3(2), page 251-282 July 2020

[20] Statement of Financial Accounting Standards (PSAK) No. 31

[21] PT Bank Central Asia Tbk. 2019. BCA 2019 Annual Report [Online]. Jakarta (ID): Indonesia Stock Exchange. [July 15, 2020]. Available: http://www.idx.co.id.

[22] PT Bank Central Asia Tbk. 2019. BCA 2019 Annual Report [Online]. Jakarta (ID): Bank Central Asia. [July 15, 2020]. Available: http://www.bca.co.id/

[23] PT Bank Mandiri Tbk. 2019. Mandiri 2019 Annual Report [Online]. Jakarta (ID): Indonesia Stock Exchange. [July 15, 2020]. Available: http://www.idx.co.id.

[24] PT Bank Mandiri Tbk. 2019. Mandiri 2019 Annual Report [Online]. Jakarta (ID): Bank Mandiri. [July 15, 2020]. Available: http://bankmandiri.co.id/

[25] Mointi, R. 2019. "Comparative Analysis of the Financial Performance of State owned banks and Private Banks". AkMen Scientific Journal. Vol 16 (1)

[26] Santoso, Singgih. 2014. Multivariate Statistics Concepts and Applications with SPSS. Revised Edition. Jakarta:

[27] Sari.T.M.,Syam.D.,Ulum.I 2012 Influence Of Non Performing Loans As Impact Global Financial Crisis On Profitability Journal of Accounting\& Investement Vol 13 No.2

[28] Siallagan, P \& Yuyetta, E. N. A. 2016. "Comparative Analysis of Financial Performance in the Banking Sector with the Camel Method in Indonesia (Comparative Study: BPD, State-Owned Banks, National Private Banks, and Foreign Banks)". Accounting journal. Vol 5 (4)

[29] Silalahi, C. V. 2018. "Comparative Analysis of the Financial Performance of State-Owned Banks with Private Banks Listed on the Indonesian Stock Exchange (IDX) Using the Camels Method (2013-2016 Period)". Thesis Thesis Summary, STIE YKPN

[30] Subramanyam, K. R. and John J. Wild. 2014. Book 2. Edition 10. Financial Statement Analysis. Jakarta : Salemba Empat

[31] Sugiyono 2015. Combination Research Methods (Mix Methods). Bandung: Alphabeta
[32] Sugiyono. 2017. Educational Research Methods Quantitative, Qualitative, and R\&D Approaches. Bandung: Alphabeta

[33] Supit, Thessalonica S.F., et al. 2019. "Comparative Analysis of the Financial Performance of State-Owned Banks and National Private Banks Listed on the Indonesia Stock Exchange". Journal of EMBA.Vol 7 (8)

[34] Quyen. Gia Phan, Nguyen Tran Thai Ha.,Susilo Nur Aji Cokro Darsono, Tran Dang Thanh Min Income Diversification and Financial Performance: The Mediating Effect of Banks' Size, Ownership Structure, and the Financial Crisis in Vietnam Journal nal Accounting \& Accounting Investment vol 22 No. 2 